Клименко О. С., кандидат ветеринарних наук

Полтавська державна аграрна академія

\title{
ТЕРАПЕВТИЧНА ЕФЕКТИВНІСТЬ РЕФЕКТИНУ І ТЕКТІНУ СУПЕР ЗА ФАСЦІОЛЬОЗУ Й ПАРАМФІСТОМОЗУ ВЕЛИКОЇ РОГАТОЇ ХУДОБИ
}

\section{Рецензент - кандидат ветеринарних наук Ж. О. Передера}

Наведено результати порівняння терапевтичної ефективності протипаразитарних препаратів «Рефектин» $i$ «Тектін супер» виробництва арабських компаній «Авіко» та «Мобедко-вет», які нещчодавно з'явилися у вільному продажу на території України і рекомендовані для лікування сільськогосподарських тварин. Результати досліджень свідчать, щзо за змішаної фасиіольозно-парамфістомозної інвазії великої рогатої худоби «Рефектин» у терапевтичній дозі забезпечує $100 \%$ екстенс- та інтенсефективність. "Тектін супер» виявився високоефективним лише для лікування тварин, хворих на фасиіольоз (ЕE та IE-100\%), а за парамфістомозу жуйних лише знижував інтенсивність інвазї.

Ключові слова: «Рефектин», «Тектін супер», фасиіольоз, парамфістомоз, велика рогата худоба, екстенсефективність, інтенсефективність.

Постановка проблеми. Беззаперечним залишається той факт, що гельмінтози завдають непоправних збитків галузі скотарства в країнах усього світу. В Україні найбільшого поширення набули трематодози великої рогатої худоби. Одним із найдієвіших заходів боротьби 3 фасціольозом, дикроцеліозом та парамфістомозом жуйних тварин залишається хіміотерапія, тобто використання антигельмінтиків. Ринок терапевтичних протигельмінтозних засобів перенасичений торговими марками, однак у більшості випадків діючі речовини майже скрізь одинакові, а нові препарати містять комбінації різних субстанцій. Оскільки фармацевтичні компанії різних країн пропонують до використання нові засоби, то випробування й вибір ефективних антигельмінтиків залишаютья актуальними завданнями в умовах сучасного виробництва.

Аналіз останніх досліджень і публікацій, у яких висвітлюсться дане питання. Перевірка терапевтичної ефективності ветеринарних препаратів залишається важливим завданням наукових лабораторій, оскільки це дає змогу надавати рекомендації практичним лікарям ветеринарної медицини щодо їх використання у господарст- вах. Для лікування великої рогатої худоби за фасціольозу, дикроцеліозу та парамфістомозу вітчизняними виробниками запропоновано бронтел, комбітрем, рафензол, трематозол (НВФ «Бровафарма»), клозаверм-А (ПНП «Укрзооветпромпостач»), альбендазол К та розчин клозантелу $10 \%$ (ВФ «Базальт»), клозантел-50 (ТОВ «Продукт»), клозавет 10 \% (ТОВ «Ветсинтез») та інші.

Про високу терапевтичну ефективність комбітрему за фасціольозу великої рогатої худоби повідомляють дослідники Сумщини та Слобожанщини [3; 5]. В умовах центральної частини України вченими отримано 100-відсоткову ефективність рафензолу за парамфістоматидозів жуйних, що підтверджувалося копроовоскопічними дослідженнями та методами гельмінтологічного розтину $[6,7]$. Інші вчені підтверджують 100-відсоткову ефективність цього препарату за фасціольозу, дикроцеліозу, парамфістомозу та стронгілятозах органів травлення великої рогатої худоби $[1,2]$. Бронтел $10 \%$ за дикроцеліозу овець у господарствах лісостепової зони України забезпечував 53,3 \% екстенсефективність і 76,3\% інтенсефективність [4]. Однак у доступних літературних джерелах практично відсутня інформація про ефективність більшості вітчизняних препаратів та завезених із-за кордону.

Метою нашої роботи було визначити і порівняти терапевтичну ефективність нових антигельмінтиків «Рефектин» (виробництва сирійської фірми «Авіко») і «Тектін супер» («Мобедковет») за фасціольозно-парамфістомозної інвазії великої рогатої худоби в умовах господарств Полтавської області.

Матеріали і методи досліджень. «Рефектин» (виробництва сирійської фармацевтичної компанії «Авіко») рекомендовано для лікування жуйних тварин і свиней, уражених гельмінтами, кліщами та комахами. Препарат $\left(1 \mathrm{~cm}^{3}\right)$ містить діючі речовини: івермектин - 10 мг, рафоксанід - 125 мг.

«Тектін супер» виробляється арабською фірмою «Мобедко-вет». Препарат $\left(1 \mathrm{~cm}^{3}\right)$ містить івермектин 10 мг, клорсулон 100 мг і рекомендо- 
ваний для лікування шлунково-кишкових, легеневих нематодозів, печінкових трематодозів, лоаозів, акарозів та ентомозів великої рогатої худоби та овець. Антигельмінтики використовуються підшкірно у дозі $1 \mathrm{~cm}^{3}$ на 50 кг маси тіла.

Дослідження проводили в господарствах різної форми власності Гадяцького й Котелевського районів Полтавської області та лабораторії кафедри паразитології та ветсанекспертизи Полтавської державної аграрної академії. 3 метою діагностики трематодозів у тварин відбирали проби фекалій і досліджували їх стандартизованим методом послідовних промивань. Хворих тварин розподілили на дві групи: коровам дослідних груп (5 і 6 голів відповідно) використали «Рефектин» та «Тектін супер» одноразово підшкірно в дозі $1 \mathrm{~cm}^{3} / 50$ кг маси тіла, тварини контрольних груп (5 і 6 голів) препаратів не отримували. Проби фекалій від тварин досліджували через 14 і 45 днів після дегельмінтизації.

Результати досліджень. До лікування у тварин першої дослідної групи інтенсивність ураження фасціолами становила $2,67 \pm 0,68-4,4 \pm 1,72$, a парамфістомами - 4,66 $\pm 2,18-7,16 \pm 2,17$ екз. яєць/1 г за екстенсивності інвазії 100 \% (табл. 1).

Через 14 діб після застосування «Рефектину» в пробах фекалій тварин яєць фасціол не виявляли, тоді як екстенсивність парамфістомозної інвазії становила $20 \%$ при інтенсивності $0,71 \pm 0,17$ екз. яєць $/ 1$ г. У тварин, яких не лікували, ЕІ ста-

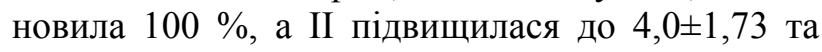
5,66 $\pm 2,66$ відповідно.

На 45-у добу після лікування в зразках відібраного матеріалу тварин дослідних груп яєць трематод не виявляли, тоді як у корів першої контрольної групи інтенсивність трематодозної інвазії зросла до $6,0 \pm 2,52$, а другої - 9,66 $\pm 3,52$ екз. яєць/1 г.

Ураженість тварин другої дослідної групи була подібною: екстенсивність фасціольозної та парамфістомозної інвазій становила $100 \%$ за інтенсивності - 2,5 $\pm 1,3 \ldots .5,23 \pm 0,33$ екз. яєць в 1 г фекалій, а тварин контрольної групи: $2,32 \pm 0,98 \ldots 4,3 \pm 1,36$ екз. яєць в 1 г за ЕI $100 \%$ (табл. 2).

Через два тижні після лікування ураженість фасціолами тварин дослідної групи становила $16,66 \%$, II - 2,3 $\pm 0,33$ екз. яєць в 1 г фекалій, а

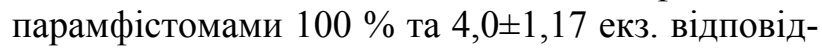
но. У тварин контрольної групи показники ураження гельмінтами майже не зазнали змін.

\section{1. Ефективність «Рефектину» за фасціольозно-парамфістомозної інвазї великої рогатої худоби}

\begin{tabular}{|c|c|c|c|c|c|c|c|c|}
\hline \multirow{4}{*}{$\begin{array}{c}\text { Період } \\
\text { дослідження }\end{array}$} & \multicolumn{8}{|c|}{ Показники ураження тварин } \\
\hline & \multicolumn{4}{|c|}{ фасціолами } & \multicolumn{4}{|c|}{ парамфістомами } \\
\hline & \multicolumn{2}{|c|}{$\begin{array}{c}\text { дослідна група } \\
(\mathrm{n}=5)\end{array}$} & \multicolumn{2}{|c|}{$\begin{array}{c}\text { контрольна група } \\
(\mathrm{n}=5)\end{array}$} & \multicolumn{2}{|c|}{$\begin{array}{c}\text { дослідна група } \\
(\mathrm{n}=5)\end{array}$} & \multicolumn{2}{|c|}{$\begin{array}{c}\text { контрольна група } \\
(\mathrm{n}=5)\end{array}$} \\
\hline & EI, \% & $\begin{array}{c}\text { II, екз. яєць } \\
\text { в } 1 \text { г }\end{array}$ & EI, \% & $\begin{array}{c}\text { II, екз. яєць } \\
\text { в } 1 \text { г }\end{array}$ & EI, \% & $\begin{array}{c}\text { II, екз. яєць } \\
\text { в } 1 \text { г }\end{array}$ & EI, \% & $\begin{array}{c}\text { II, екз. яєць } \\
\text { в } 1 \text { г }\end{array}$ \\
\hline До лікування & 100 & $4,4 \pm 1,72$ & 100 & $2,67 \pm 0,68$ & 100 & $7,16 \pm 2,17$ & 100 & $4,66 \pm 2,18$ \\
\hline $\begin{array}{c}\text { Через } 14 \text { діб } \\
\text { після лікування }\end{array}$ & - & $0 \pm 0$ & 100 & $4,0 \pm 1,73$ & 20 & $0,71 \pm 0,17$ & 100 & $5,66 \pm 2,66$ \\
\hline $\begin{array}{c}\text { Через } 45 \text { діб } \\
\text { після лікування }\end{array}$ & - & $0 \pm 0$ & 100 & $6,0 \pm 2,52$ & - & $0 \pm 0$ & 100 & $9,66 \pm 3,52$ \\
\hline
\end{tabular}

\section{2. Ефективність «Тектіну супер» за фасціольозно-парамфістомозної інвазії великої рогатої худоби}

\begin{tabular}{|c|c|c|c|c|c|c|c|c|}
\hline \multirow{4}{*}{$\begin{array}{c}\text { Період } \\
\text { дослідження }\end{array}$} & \multicolumn{8}{|c|}{ Показники ураження тварин } \\
\hline & \multicolumn{4}{|c|}{ фасціолами } & \multicolumn{4}{|c|}{ парамфістомами } \\
\hline & \multicolumn{2}{|c|}{$\begin{array}{c}\text { дослідна група } \\
\text { (n=6) }\end{array}$} & \multicolumn{2}{|c|}{$\begin{array}{c}\text { контрольна група } \\
(\mathrm{n}=6)\end{array}$} & \multicolumn{2}{|c|}{$\begin{array}{l}\text { дослідна група } \\
(\mathrm{n}=6)\end{array}$} & \multicolumn{2}{|c|}{$\begin{array}{c}\text { контрольна група } \\
(\mathrm{n}=6)\end{array}$} \\
\hline & EI, \% & $\begin{array}{c}\text { II, екз. яєць } \\
\text { в } 1 \text { г }\end{array}$ & EI, \% & $\begin{array}{c}\text { II, екз. яєць } \\
\text { в } 1 \text { г }\end{array}$ & EI, \% & \begin{tabular}{|c|} 
II, екз. яєць \\
в 1 г
\end{tabular} & EI, \% & $\begin{array}{c}\text { II, екз. яєць } \\
\text { в } 1 \text { г }\end{array}$ \\
\hline До лікув & 100 & $2,5 \pm 1,3$ & 100 & $2,32 \pm 0,98$ & 100 & $5,23 \pm 0,33$ & 100 & $4,3 \pm 1,36$ \\
\hline $\begin{array}{c}\text { Через } 14 \text { діб після } \\
\text { лікування }\end{array}$ & 16,66 & $2,3 \pm 0,33$ & 100 & $2,53 \pm 0,68$ & 100 & $4,0 \pm 1,17$ & 100 & $4,46 \pm 1,18$ \\
\hline $\begin{array}{c}\text { Через } 45 \text { діб після } \\
\text { лікування }\end{array}$ & - & $0 \pm 0$ & 100 & $3,0 \pm 0,73$ & 100 & $4,2 \pm 0,66$ & 100 & $5,56 \pm 2,32$ \\
\hline
\end{tabular}


3. Ефективність антигельмінтиків за фасціольозно-парамфістомозної інвазії великої рогатої худоби (через 45 діб після лікування)

\begin{tabular}{|c|c|c|c|c|}
\hline \multirow{2}{*}{ Препарат } & \multicolumn{2}{|c|}{ Фасціольоз } & \multicolumn{2}{c|}{ Парамфістомоз } \\
\cline { 2 - 5 } & EE, \% & IE, \% & EE, \% & IE, \% \\
\hline «Рефектин» & 100 & 100 & 100 & 100 \\
\hline «Тектін супер» & 100 & 100 & - & 32,52 \\
\hline
\end{tabular}

На 45-у добу спостереження в зразках фекалій тварин дослідної групи виявляли лише яйця парамфістом: інтенсивність інвазії становила 4,2士0,66 екз. яєць в 1 г фекалій при ЕI $100 \%$.

Отримані дані свідчать, що «Рефектин» забезпечує високий терапевтичний ефект за фасціольозно-парамфістомозної інвазії великої рогатої худоби: екстенс- та інтенсефективність сягали $100 \%$ (табл. 3).

«Тектін супер» проявляв високу терапевтичну дію за фасціольозу (ЕE - 100 \%, IE - 100 \%), а за парамфістомозу лише знижував інтенсивність інвазії (IE - 32,52 \%).

\section{БІБЛІОГРАФІЯ}

1. Дахно І. С. Лікувальна ефективність рафензолу за фасціольозу, парамфістомозу та стронгілятозів органів травлення у великої рогатої худоби / I. С. Дахно, Г. П. Дахно, К. П. Жданова [та ін.] // Вісник Полтавської ДАА. - Полтава, 2007. - №3. - С. 39-41.

2. Дахно I. С. Терапевтична ефективність рафензолу за змішаних гельмінтозів у великої рогатої худоби / І. С. Дахно, О. В. Кручиненко, Г. П. Дахно // Матеріали Міжнародної науково-практичної конференції молодих вчених Сумського НАУ [«Аграрний форум - 2007»]. - Суми, 2007. - Ч. I. - C. 119-120.

3. Дахно І. С. Протифасціольозні заходи у тваринницьких господарствах молочного напрямку / I. С. Дахно, Г. П. Дахно // Вісник СНАУ. Суми, 2010. - № 3 (26). - С. 41-45.

4. Дахно І. С. Ефективність бронтелу $-10 \%$ за
Отримані дані свідчать, що антгельмінтики проявляють високу лікувальну дію за фасціольозу великої рогатої худоби. За змішаної трематодозної інвазії рекомендовано використовувати лише рефектин.

\section{Висновки:}

1. Екстенс- та інтенсефективність «Рефектину» в терапевтичній дозі за фасціольозу й парамфістомозу великої рогатої худоби становить $100 \%$.

2. «Тектін супер» забезпечує високу терапевтичну ефективність лише за фасціольозу великої рогатої худоби.

дикроцеліозу овець / I. С. Дахно, С. А. Ничик, Г. П. Дахно // Науковий вісник НУБіП України. - 2011. - Вип. 167. - Част.1. - С. 128-134.

5. Мазанний О. В. Фасціольозно-парамфістомозна інвазія великої рогатої худоби (особливості епізоотології, діагностика та заходи боротьби) : Автореф. дис. ... канд. вет. наук : 16.00.11 - паразитологія, гельмінтологія / О. В. Мазанний. K., 2006. -23 c.

6. Рекомендації з діагностики та заходів боротьби 3 парамфістоматидозами великої рогатої худоби / А. В. Березовський, В. Ф. Галат, А. М. Шевченко. - Ветінформ, 2006. - 20 с.

7. Шевченко А. М. Парамфістоматидози жуйних тварин (епізоотологія, діагностика, лікування i профілактика) : Автореф. дис. ... канд. вет. наук : 16.00.11 - паразитологія, гельмінтологія / А. М. Шевченко. - К., 2006. -23 с. 